\title{
Late Cornified Envelope Protein 3B
}

National Cancer Institute

\section{Source}

National Cancer Institute. Late Cornified Envelope Protein 3B. NCI Thesaurus. Code C131199.

Late cornified envelope protein 3B (95 aa, $10 \mathrm{kDa}$ ) is encoded by the human LCE3B gene. This protein is involved in keratin formation in the epidermis. 